\title{
Hubungan antara Gaya Kepemimpinan Transformasional dan Iklim Organisasi dengan Perilaku Kewarganegaraan Organisasi (Ocb) pada Karyawan PT. Telkom
}

\author{
Indira Maharani, Agustin Handayani \\ Fakultas Psikologi Universitas Islam Sultan Agung Semarang \\ agustinhandayani75@gmail.com
}

\begin{abstract}
Abstrak
Penelitian ini bertujuan untuk melihat hubungan antara gaya kepemimpinan transformasional dan iklim organisasi dengan perilaku kewarganegaraan organisasi (OCB) pada karyawan PT. Telkom. Penelitian ini menggunakan metode kuantitatif korelasional. Sampel penelitian ini berjumlah 97 karyawan PT. Telkom. Teknik dalam pengambilan sample dengan menggunakan teknik cluster random sampling. Alat ukur yang digunakan dalam penelitian ini terdiri dari tiga skala, yaitu Skala perilaku kewarganegaraan organisasi (OCB), skala gaya kepemimpinan transformasional dan skala iklim organisasi. Uji hipotesis dalam penelitian ini menggunakan analisis regresi dua prediktor, uji hipotesis kedua dan ketiga menggunakan analisis korelasi parsial.

Hasil uji hipotesis pertama menunjukkan adanya hubungan antara gaya kepemimpinan transformasional dan iklim organisasi dengan perilaku kewarganegaraan organisasi $(O C B)$ diperoleh $\operatorname{Ry}(1,2)=0,603$ dan Fhitung $=26,828$ dengan signifikansi $p=0,000(p<0,05)$ yang berarti hipotesis ini diterima. Uji hipotesis kedua yang dilakukan antara variabel gaya kepemimpinan transformasional dengan perilaku kewarganegaraan organisasi (OCB) dengan melakukan kontrol iklim organisasi diperoleh $r \times 1 y=0,364$ dengan $p=0,000(p<$ 0,01 ). Hasil tersebut menunjukkan bahwa ada hubungan positif yang sangat signifikan antara gaya kepemimpinan transformasional dengan perilaku kewarganegaraan organisasi, sehingga hipotesis kedua diterima.

Hasil uji hipotesis ketiga antara variabel iklim organisasi dan perilaku kewarganegaraan organisasi (OCB) dengan melakukan kontrol variabel gaya kepemimpinan transformasional diperoleh $r \times 2 y=0,577$ dengan $p=0,000(p<0,01)$. Hasil tersebut menunjukkan bahwa ada hubungan positif yang sangat signifikan antara iklim organisasi dengan perilaku kewarganegaraan organisasi (OCB) yang berarti hipotesis ketiga diterima.
\end{abstract}

Kata Kunci : Perilaku Kewarganegaraan Organisasi (OCB), Gaya Kepemimpinan Transformasional, Iklim Organisasi 


\section{Pendahuluan}

Pada era ini persaingan antar organisasi sangatlah kuat terjadi, hal ini dapat diatasi dengan melakukan perubahan pada organisasi. Perubahan ini dapat dilakukan dengan cara mencari sumber daya manusia yang mampu bersaing dengan organisasi lainnya. Organisasi membutuhkan sumber daya manusia yang memiliki kemampuan kinerja yang baik dalam team work. Kinerja karyawan ini bisa dilihat dari individu yang tidak hanya bekerja berdasarkan job descriptionnya saja, namun ikut serta untuk menyelesaikan pekerjaan secara keseluruhan didalam organisasi. Pekerjaan yang dilakukan karyawan bukan hanya pekerjaan pokok saja, tetapi ada juga tugas ekstra yaitu berpartisipasi dalam organisasi maupun dengan rekan kerja dalam menyelesaikan pekerjaanya (Lubis, 2016). Seorang karyawan yang turut serta berkontribusi diluar dari job des criptionnya bisa disebut dengan perilaku kewarganegaraan organisasi (OCB). Namun pada kenyataannya tidak semua karyawan memiliki perilaku kewarganegaraan organisasi (OCB) yang baik.

PT. Telekomunikasi Indonesia adalah salah satu badan usaha milik negara yang bergerak di bidang jasa pelayanan telekomunikasi seperti interkoneksi, jaringan, data, internet, serta layanan lain di wilayah Indonesia. Adapun yang terkait dalam menunjukkanpelayanan jaringan telekomunikasi yang unggul serta layanan komunikasi berkualitas tinggi sehingga diharapkan dapat melayani kebutuhan masyarakat dalam hal pemenuhan jaringan komunikasi secara utuh. Semua tidak lepas dari kinerja karyawannya. Karyawan adalah salah satu pihak yang mempunyai pengaruh yang tinggi bagi organisasi. Kinerja karyawan di dalam perusahaan dapat memberikan kontribusi positif dalam kemajuan perusahaan.

Perilaku kewarganegaraan organisasi (OCB) merupakan kinerja extra-role yaitu perilaku karyawan dalam membantu rekan kerja yang mendapatkan kesulitan dalam pekerjaan seperti pekerjaan yang belum selesai untuk di kerjakan. Fungsi dari $O C B$ adalah mencegah ancaman yang berdampak pada kerugian yang akan dialami organisasi dan perilaku untuk menciptakan kenyamanan ditempat kerja atau 
PSISULA : Prosiding Berkala Psikologi

Vol. 1, 2019

E-ISSN: 2715-002X

perilaku positif. Perilaku positif berguna agar karyawan dapat mengerjakan pekerjaan lebih dari yang sudah ditentukan. Perilaku karyawan ini dapat membantu organisasi menjadi efektif dan memajukan organisasi serta menguntungkan organisasi dengan adanya perilaku yang baik yang tumbuh di dalam diri individu. Namun kenyataan yang ada pada karyawan PT. Telkom tidak semua karyawan memiliki $O C B$ yang baik. Rendahnya OCB pada karyawan ini dapat memberikan dampak buruk bagi organisasi.

Permasalahan atas rendahnya OCB pada karyawan PT. Telkom ini terjadi karena karyawan di sana bekerja hanya mementingkan gaji saja, bukan menunjukkan kinerja yang baik untuk kemajuan maupun keuntungan bagi organisasi, kurangnya rasa peduli terhadap permasalahan yang terjadi pada organisasi, dan kurang adanya hubungan yang baik antara rekan kerja. Karyawan lebih mementingkan untuk menyelesaikan pekerjaannya sendiri karena merasa beban yang dilakukan sudah berat. Alasan lain adalah karyawan kurang memiliki kemauan untuk menolong antar rekan kerja yang kesulitan dalam menyelesaikan pekerjaan. Lembur juga menjadi alasan mengapa tingkat OCB pada karyawan PT. Telkom rendah.

Kepemimpinan ternyata menjadi salah satu yang berpengaruh dalam pembentukan perilaku OCB karena dengan terciptanya kepemimpinan yang baik menjadikan organisasi menjadi lebih efektif. Setiap perilaku yang dilakukan pemimpin dalam organisasi memiliki cara yang berbeda atau bisa dikatakan dengan gaya kepemimpinan.

Gaya kepemimpinan setiap pemimpin menjadi tolak ukur bagi karyawan dalam berperilaku di organisasi dengan dipengaruhi dari pemimpin sendiri (Gunawan, 2016). Namun pada kenyataanya gaya kepemimpinan yang diterapkan dalam organisasi tidak semuanya berpengaruh dalam pembentukan OCB pada karyawan. Gaya yang dapat mempengaruhi dalam perilaku OCB pada karyawan adalah gaya kepemimpinan yang mampu mengedepankan karyawan dalam bekerja sehingga organisasi mampu bersaing dengan organisasi lainnya. Gaya yang dapat 
PSISULA : Prosiding Berkala Psikologi

Vol. 1, 2019

E-ISSN: 2715-002X

membantu kemajuan organisasi adalah gaya kepemimpinan yang berorientasi pada hubungan atau dapat dikatakan dengan gaya kepemimpinan transformasional.

Terciptanya iklim organisasi yang dapat menumbuhkan rasa nyaman dan harmonis, akan membuat karyawan lebih bersemangat sehingga dapat melakukan pekerjaan dengan baik (Wahyu Susihono, 2012). Iklim organisasi menjadi salah satu faktor yang dapat mempengaruhi OCB karyawan dalam bekerja, iklim organisasi yang dibentuk sesuai dengan prosedur dan aturan, akan mendukung kinerja karyawan, sehingga akan muncul persepsi yang positif dalam diri individu terhadap organisasi (Kartika Sari Dewi, 2010). Iklim dapat diukur dari seberapa jauh individu dibangun, dirahkan dan mendapatkan penghargaan atas kinerjanya dari perusahaan. Namun iklim organisasi yang diterapkan setiap organisasi berbedabeda. Iklim organisasi pada PT. Telkom termasuk dalam kategori iklim organisasi yang kurang mendukung karyawan dalam menumbuhkan perilaku kewarganegaraan organisasi (OCB).

\section{Metode}

Metode pengumpulan data berupa skala perilaku kewarganegaraan organisasi (40 aitem) yang menggunakan aspek dari (Bateman \& Organ, 2014) Conscientiouness, altruism, civic virtue, sportmanship, dan courtesy. Skala gaya kepemimpinan transformasional (40 aitem) yang diungkap pada aspek oleh (Bass, 2010) antara lain yaitu Kharisma, motivasi inspirasional, stimulasi intelektual, dan perhatian individu. Skala iklim organisasi (30 aitem) pada aspek yang dikemukakan oleh (Wirawan, 2008) antara lain yaitu Struktur, tanggung jawab, penghargaan, dukungan, dan komitmen.

Uji daya beda menggunakan regresi dua prediktor. Penelitian ini menguji reliabilitas menggunakan koefisien reliabilitas Alpha Cronbach. Teknik analisis data yang digunakan dalam penelitian ini yaitu regresi dua prediktor untuk menguji hipotesis. Perhitungan statistik dalam penelitian ini dibantu oleh program SPSS (Statistical Product and Service Solution) versi 16. 


\section{Hasil dan Diskusi}

Hasil uji hipotesis menggunakan regresi dua prediktor diperoleh $\mathrm{R}$ sebesar rxy $=0,603$ dan nilai Fhitung $=26,828$ dengan $p=0,000(p<0,05)$, hasil tersebut menjelaskan bahwa terdapat hubungan antara gaya kepemimpinan transformasional dan iklim organisasi dengan $O C B$, dengan sumbangan efektif sebesar $36,3 \%$.

Penelitian ini dilakukan untuk mengetahui hubungan antara gaya kepemimpinan transformasional dan iklim organisasi dengan perilaku kewarganegaraan organisasi (OCB) pada karyawan PT. Telkom. Berdasarkan hasil pengujian hipotesis diketahui ada hubungan positif yang signifikan antara gaya kepemimpinan transformasional dan iklim organisasi dengan perilaku kewarganegaraan organisasi (OCB). Semakin tinggi gaya kepemimpinan transformasional dan iklim organisasasi maka semakin tinggi pula perilaku kewarganegaraan organisasi. Diperoleh hasil $R$ sebesar $r x y=0,603$ dengan signifikansi $=0,000(p<0,05)$.

Penelitian ini dilakukan dengan tujuan untuk mengetahui apakah ada hubungan antara variabel bebas dengan variabel tergantung. Berdasarkan hasil penelitian yang telah dilakukan, penelitian ini memiliki hipotesis yang diuji. Hipotesis tersebut yaitu untuk menguji apakah ada hubungan yang positif antara gaya kepemimpinan transformasional dan iklim organisasi dengan perilaku kewarganegaraan organisasi pada karyawan PT.Telkom. Berdasarkan uji linieritas hubungan antara perilaku kewarganegaraan dengan gaya kepemimpinan diperoleh nilai $F_{\text {linear }}=14,548$ dengan $p=0,000(p \leq 0,05)$ dan uji linieritas hubungan antara perilaku kewarganegaraan dengan iklim organisasi diperoleh nilai $F_{\text {linear }}=47,513$ dengan $p=0,000(p \leq 0,05)$.

Hasil penelitian menunjukkan bahwa OCB termasuk dalam kategori tinggi. Hasil analisis deskriptif yaitu responden $62(63,91 \%)$ menunjukkan OCB yang tinggi. Hal ini berarti bahwa OCB karyawan dalam pekerjaan dapat dikatakan baik. 
PSISULA : Prosiding Berkala Psikologi

Vol. 1, 2019

E-ISSN: 2715-002X

Ada beberapa faktor yang mempengaruhi OCB itu sendiri. Berdasarkan hasil uji hipotesis yang kedua diperoleh koefisien korelasi ry2-1 $=0,364$ dengan $p=0,000$ $(p<0,01)$. Hasil tersebut menunjukkan bahwa ada hubungan positif dan sangat signifikan antara gaya kepemimpinan tranformasional dengan OCB. Hasil penelitian ini sejalan dengan hasil penelitian oleh I komang adi (2016) mengenai pengaruh gaya kepemimpinan transformasional dengan OCB yang membuktikan bahwa gaya kepemimpinan transformasional memberikan sumbangan $49,489 \%$ terhadap OCB karyawan.

Selain faktor gaya kepemimpinan transformasional, faktor iklim organisasi juga berpengaruh terhadap OCB. Berdasarkan hasil uji hipotesis ketiga di peroleh koefisien korelasi ry2-1 $=0,577$ dengan $p=0,000(p<0,01)$. Hasil ini menjelaskan bahwa terdapat hubungan positif yang sangat signifikan antara iklim organisasi dengan OCB.

Hal tersebut dibuktikan oleh penelitian (Imran, 2010) yang menyatakan bahwa iklim organiasai memiliki pengaruh yang positif dan signifikan dengan OCB, dapat diartikan bahwa OCB karyawan akan meningkat apabila terjadi peningkatan pada iklim organisasi, yaitu meliputi karyawan dapat kesempatan dalam berpendapat, karyawan bertanggung jawab dalam pekerjaan dan perasaan bahagia dapat menyelesaikan pekerjaan dengan lancar.

\section{Kesimpulan}

Pembahasan di atas dapat di ambil kesimpulan bahwa gaya kepemimpinan transformasional dan iklim organisasi berhubungan sangat signifikan dengan OCB. Makin positif gaya kepemimpinan transformasional dan iklim organisasi, maka akan meningkatkan OCB pada karyawan. 


\section{Daftar Pustaka}

Azwar, S. (2012). Penyusunan Skala Psikologi. Alih bahasa: Edy Suhardono. Jogjakarta: Pustaka Pelajar.

Bass B.M. (2010) Predicting Unit Performance by assesing Transformational and Transactional Leadership. Journal of Applied Psycology, 88(2) 207-218

Bateman, T. S., \& Organ, D. W. (2004). Job satisfaction and the good soldier: The relationship between affect and employee "citizenship". Academy of Management Journal, 26(4), 587-595.

Gunawan, R. (2016). Pengaruh kepemimpinsan transformasional terhadap organizational citizenship behavior (OCB) pada PT First Marchinery Tradeco Cabang Surabaya. Agora, 4(1), 60-66.

Imran. (2010). Pengaruh iklim organisasi dan komitmen organisasi terhadap organizational citizenship behavior (OCB). Jurnal Equlibrium, 6(1), 2089-2152.

Lubis, A. (2016). Implementasi dimensi organizational citizenship behavior (OCB) dengan kinerja organisasi. El-Qanuniy, 2(1), 111-122.

Prihatsanti, U \& Dewi, K.S. (2010). Hubungan antara Iklim Organisasi dan Organizational Citizenship Behavior (OCB) pada Guru SD Negeri di Kecamatan Mojolaban Sukoharjo. Jurnal Psikologi Undip. 7(1), 11-17.

Susihono, W (2012). Pengaruh iklim organisasi dan pengembangan karir terhadap kepuasan kerjakaryawan. Spektrum Industri , 10 (2), 108-199.

Wirawan. (2008). Evaluasi Kinerja Sumber Daya Manusia : Teori Aplikasi dan Penelitian.Alih Bahasa Drs. Benjamin Molan. Jakarta: Salemba Empat 
PSISULA : Prosiding Berkala Psikologi

Vol. 1, 2019

E-ISSN: 2715-002X 